\title{
Digestion and utilization of fructose polymers by the rumen bacterium Treponema sp. strain T
}

\author{
A. Kasperowicz ${ }^{1}$ and T. Michalowski \\ The Kielanowski Institute of Animal Physiology and Nutrition, Polish Academy of Sciences \\ 05-110 Jablonna, Poland
}

(Received 24 August 2007; revised version 9 October 2007; accepted 21 November 2007)

\begin{abstract}
In this experiment, strain $\mathrm{T}$ of ruminal treponemes was studied regarding the ability to utilize $\beta-2,6-$ and $\beta-2,1$-fructose polymers as well as sucrose and fructose. Bacteria were able to grow on laboratory-prepared timothy grass fructan and commercial inulin, but not on sucrose or fructose. The optical density of cultures growing on inulin and timothy grass fructan was 0.5 and 1.1 absorbance units, respectively. Bacteria utilized up to $80 \%$ of the timothy grass fructan and only $30 \%$ of inulin during a $24 \mathrm{~h}$ incubation period. It was found that bacteria utilized only the $\beta-2,1$-inulooligosaccharides present in the commercial inulin while the long-chain polysaccharides remained undigested. Enzymatic studies showed that the bacterial cell-free extract degraded the timothy grass fructan, inulin and sucrose, releasing 13.4-19.1, 11.1-14.9 and 42.4-52.9 $\mu \mathrm{M}$ fructose/mg protein/h, respectively. It is suggested that enzymes involved in the degradation of fructose polymers could form a complex of which the enzyme specifically digesting the timothy grass fructan is associated with the outer membrane and acts on cell surfaces, while unspecific $\beta$-fructofuranosidase occupies an intracellular space and digests only the carbohydrates inside the bacterial cells. It is also suggested that such a localization of enzymes could be responsible for the inability of bacteria to utilize long-chain inulin. It is supposed that the examined bacteria are lacking in mechanism(s) transporting sucrose and fructose from the growth medium to the intracellular space of these microorganisms.
\end{abstract}

KEY WORDS: rumen treponemes, timothy grass fructan, inulin, fructanolytic enzymes

\section{INTRODUCTION}

Fructans are carbohydrates composed of $\beta$-D-fructose residues linked by either 2,6 or 2,1 glycosidic bonds and according to this they are called levans or inulins, respectively. Levans occur in grasses, while inulins, in Compositae. Many

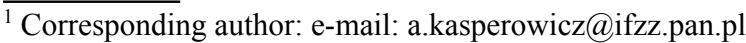


species of plants belonging to the mentioned groups are of nutritional importance to herbivores, including ruminants. Information on the digestion and metabolism of fructose polymers in the digestive tract of these mammals remains, however, scanty. According to Chesson and Forsberg (1997) fructans are readily digested and fermented by microorganisms inhabiting in the rumen. However, neither fructanolytic species of rumen microbiota nor their enzymes involved in degradation of fructose polymers in this highly specific ecosystem have been well recognized to date. The previous investigation carried out at our laboratory showed that some strains of rumen treponemes were presumably able to synthesize $\beta$-fructofuranosidase (Ziołecki et al., 1992; Guczyńska, 1999). Further studies revealed, however, that strain $\mathrm{S}$ of these microorganisms synthesized a specific endolevanse and unspecific $\beta$-fructofuranosidase (Kasperowicz and Michałowski, 2002).

The aim of this study was to characterize the ability of ruminal treponeme strain $\mathrm{T}$ to digest and utilize carbohydrates composed of fructose linked by 2,6 and 2,1 glycosidic bonds.

\section{MATERIAL AND METHODS}

\section{Organism and culture media}

Bacteria Treponema sp. strain T originated from our own culture collection. They were isolated from the rumen of sheep by Guczyńska (1999) and grown routinely in vitro. The growth medium used for cultivation of bacteria was described previously (Kasperowicz and Michałowski, 2002). Briefly, it consisted of $(\mathrm{g} / \mathrm{l})$ $0.45\left(\mathrm{NH}_{4}\right)_{2} \mathrm{SO}_{4}, 0.45 \mathrm{KH}_{2} \mathrm{PO}_{4}, 0.45 \mathrm{~K}_{2} \mathrm{HPO}_{4}, 0.9 \mathrm{NaCl}, 0.09 \mathrm{MgSO}_{4} \times 7 \mathrm{H}_{2} 0,0.09$ $\mathrm{CaCl}_{2}, 7.5 \mathrm{NaHCO}_{3}$, and distilled water. This solution was mixed with $300 \mathrm{ml}$ of clarified and pasteurized rumen fluid and supplemented with $1 \mathrm{~g}$ of casitone and yeast extract, while cysteine hydrochloride $(250 \mathrm{mg})$ and thioglycolic acid $(0.3$ $\mathrm{ml}$ ) were added as reducing agents. The timothy grass fructan, inulin, sucrose, fructose and glucose were pasteurized and added separately to the medium at a proportion of $5 \mathrm{~g} / 1$.

\section{Growth experiment}

Cultures of bacteria were initiated by introduction of $2.5 \mathrm{ml}$ of the stock cultures into $50 \mathrm{ml}$ of the medium supplemented with one of the carbohydrates mentioned above. The initiated cultures were incubated anaerobically for $24 \mathrm{~h}$ at $40^{\circ} \mathrm{C}$ and the optical density and carbohydrate content were measured just before start of incubation and 2, 4, 6, 8, 11, 13 and $24 \mathrm{~h}$ thereafter. Additionally, carbohydrates present in culture medium were identified at the start and the end of the incubation period. 


\section{Cell free extract preparation and fractionation}

Bacterial cultures were centrifuged for $25 \mathrm{~min}$ at $20000 \mathrm{~g}$ and $4^{\circ} \mathrm{C}$ and washed with $0.9 \% \mathrm{NaCl}$ solution. The pellet was suspended in distilled water, sonicated using an MSE sonicator (London, England) and centrifuged as above for $10 \mathrm{~min}$. The supernatant was then collected and used as a bacterial cell-free extract. The soluble and sedimentable fractions of this preparation were obtained by centrifugation for $1 \mathrm{~h}$ at $100,000 \mathrm{~g}$ and $4^{\circ} \mathrm{C}$. The protein associated with particulate matter was released with a $0.4 \%$ solution of Triton X-100 according to Mantsäla and Zalkin (1979). Fractionation of the soluble fraction of bacterial cell-free extract was performed on Sephadex G-150 (Pharmacia) using a $400 \times 16 \mathrm{~mm}$ glass column. A sample of the fractionated material, $1 \mathrm{ml}$ in volume, was applied to the column and eluted with a solution of $0.1 \mathrm{M} \mathrm{KCl}$ in $0.05 \mathrm{M}$ Tris/ $\mathrm{HCl}$ buffer (pH 7.5). The elution velocity was $6 \mathrm{ml} / \mathrm{h}$ and the volume of the collected fractions, $2 \mathrm{ml}$. The collected fractions were examined for ability to digest timothy grass fructan, inulin and sucrose. The identified fractions were desalted by washing with cold $\left(4^{\circ} \mathrm{C}\right)$ distilled water and condensed using an Amicon apparatus and molecular filter impermeable to molecules over $10 \mathrm{kDa}$.

\section{Enzyme assays}

A reaction mixture consisting of $0.8 \mathrm{ml}$ of $0.02 \mathrm{M}$ sodium-potassium phosphate buffer ( $\mathrm{pH} 6.0$ ), $0.25 \mathrm{ml}$ of $1 \%$ carbohydrate solution, $0.2 \mathrm{ml}$ of appropriate enzyme preparation or post-culture medium and $0.05 \mathrm{ml}$ of water was incubated for 4 and $24 \mathrm{~h}$ at $40^{\circ} \mathrm{C}$, respectively, and the released reducing sugars were quantified and identified.

Fructanolytic enzymes were identified by a zymogram technique according to Kasperowicz and Michalowski (2002). Briefly, the proteins of the cell-free extract and its appropriate fraction were separated by native electrophoresis on $6 \%$ polyacrylamide gel. Timothy grass fructan, inulin and sucrose at a final concentration of $0.2 \%(\mathrm{w} / \mathrm{v})$ were copolymerized separately with polyacrylamide to be the substrates for the identified enzymes. The gel and electrode buffer were 0.05 and $0.005 \mathrm{M}$ Tris/glycine buffers ( $\mathrm{pH} 8.3$ ), respectively. Samples of $10 \mu 1$ of the appropriate preparation were layered onto the gel and electrophoresis was carried out using a mini dual gel unit for slab electrophoresis (Sigma) at a constant current of $94 \mathrm{~V}$. The gels were then incubated for $15 \mathrm{~min}$ at $40^{\circ} \mathrm{C}$ in $0.1 \mathrm{M}$ sodium-potassium phosphate buffer ( $\mathrm{pH}$ 6.0) and fructanolytic activities were visualized with 2,3,5-triphenyltetrazolium chloride according to Gabriel and Wang (1969).

\section{End product identification}

Digestion products of timothy grass fructan and inulin were identified by thin layer chromatography (TLC). Samples $(10 \mu \mathrm{l})$ of the reaction mixture 
(see above) or post-culture medium were spotted on silica gel plates (Kavalier, Czechoslovakia and Merck, Germany) and developed three times using an n-butanol-isopropanol-acetic acid-water (35:25:20:10) mixture (v/v) according to Lüscher et al. (1993) or four times in an ethanol-butanol-water (5:5:3) mixture (Kozumi et al., 1985). Plates were visualized with a ketose-specific urea/ phosphoric acid reagent (Wise et al., 1955). Fructose and sucrose were used as standards.

\section{Quantitative measurements}

The optical density of the bacterial cultures was measured at $660 \mathrm{~nm}$. Reducing sugars released from the digested carbohydrates were quantified using the dinitrosalicylic reagent (Miller et al., 1960) with fructose as the standard, while enzyme activity was expressed as micromoles of fructose released from substrate per mg protein per $\mathrm{h}$. Total carbohydrates in the culture medium were determined by the antrone method (Southgate, 1991). Protein was assayed by the bicinchoninic acid reagent (Smith et al., 1985) using bovine serum albumin (BSA) as the standard. All measurements were performed using a Beckman DU-64 Spectrophotometer.

\section{Chemicals}

All chemicals for electrophoresis and protein determination, as well as glucose and sucrose were supplied by Sigma Chemical Co. Inulin was supplied by Merck. Inorganic reagents were from POCH Gliwice (Poland). Yeast extract and casitone were obtained from Difco Laboratories. All chemicals were of analytical grade. Timothy grass fructan was isolated and purified according to Ziołecki et al. (1992).

\section{Statistical analysis}

Mean values and their standard deviations (SD) were calculated from the quantitative results obtained. Significance of differences between mean values was examined using Student's t-test. All statistical calculations were made with Statistica software.

\section{RESULTS}

Growth of bacteria and carbohydrate utilization. Bacteria were able to grow on the timothy grass fructan and inulin but did not utilize sucrose and fructose added to the culture medium (Figures $1 \mathrm{a}$ and $\mathrm{b}$ ). The optical density of the cultures of bacteria increased significantly during the first $11-13 \mathrm{~h}$ of incubation 
a)

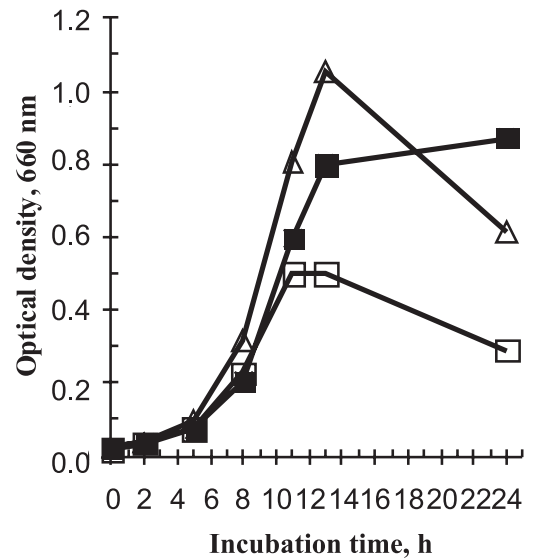

b)

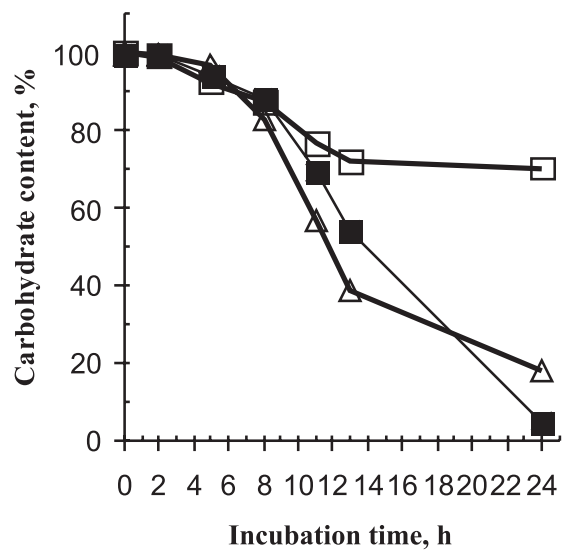

Figure 1 . The changes in population density of bacteria (a) and in concentration of carbohydrates in culture medium (b) in the relation to time of incubation and carbohydrate supplied to the culture medium. $\triangle$ - timothy grass fructan; $\square$ - inulin; $\mathbf{\square}$ - glucose

$(\mathrm{P}<0.05)$ and then decreased or remained unchanged. The growth rate of cultures maintained on the timothy grass fructan was significantly higher compared with inulin $(\mathrm{P}<0.01)$. No statistically significant difference was, however, found between the growth rate of the former and control cultures growing on glucose. The cultures maintained on timothy grass fructan were significantly less dense after 24 $\mathrm{h}$ of incubation than $11 \mathrm{~h}$ earlier $(\mathrm{P}<0.05)$, while the changes in the optical density of the remaining cultures were insignificant $(\mathrm{P}>0.05)$.

The concentration of all of the three carbohydrates supplied to the culture medium dropped during the first $13 \mathrm{~h}$ incubation of bacteria. The contents of glucose and timothy grass fructan decreased by about 50 and $60 \%$, respectively, while the decrease in the inulin content did not exceed $30 \%$ of the initial value $(\mathrm{P}<0.05)$. Only $5 \%$ of glucose and $18 \%$ of the timothy grass fructan added to the growth medium was found after $24 \mathrm{~h}$ incubation of bacteria, but the inulin concentration did not change during the last $11 \mathrm{~h}$ of the incubation period $(\mathrm{P}>0.05)$.

Identification of carbohydrates in the post-culture medium of the cultures growing on the timothy grass fructan showed the presence of only oligosaccharides (Figure 2a). Post-culture medium supplemented with inulin was characterized by the presence of only long-chain carbohydrates, while no oliogosccharides were detected there despite their presence just before the inoculation of bacteria (Figure 2b).

Fructanolytic activity. Bacterial cell-free extract digested timothy grass fructan, inulin and sucrose independently of the carbon source in the growth medium. The degradation rate varied, however, from 11.1 to $55.9 \mu \mathrm{M}$ fructose mg protein ${ }^{-1} \mathrm{~h}^{-1}$ 
a)

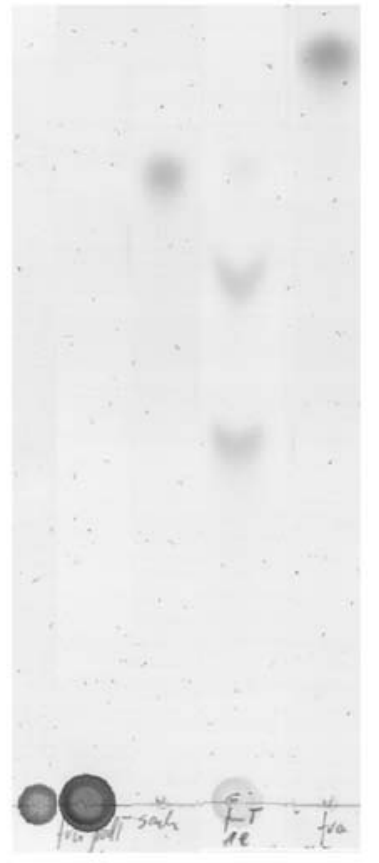

$\begin{array}{lllll}1 & 2 & 3 & 4 & 5\end{array}$ b)

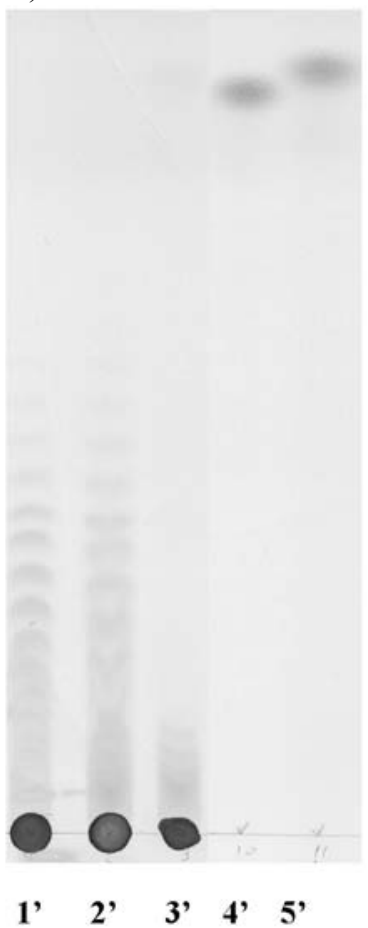

Figure 2. Carbohydrates identified just before and after incubation of bacteria in the medium supplemented with the timothy grass fructan (a) and inulin. (b). Lanes 1 and 1' - standards of the timothy grass fructan and inulin, respectively; lanes 2 and 2' - the growth medium supplemented with the timothy grass fructan and inulin, respectively; lanes 3 and 4' - sucrose standards; lanes 5 and 5'fructose standards; lanes 4 and 3'- culture medium supplemented with the timothy grass fructan and inulin after incubation of bacteria for $24 \mathrm{~h}$, respectively

and was related to the digested substrate (Table 1). The degradation rates of timothy grass fructan and inulin were of a similar magnitude, while sucrose was digested up to 4 times faster than the remaining two carbohydrates tested. No fructanolytic activity was found in the post-culture medium.

Table 1. Degradation rate of three carbohydrates $\left(\mu \mathrm{M}\right.$ released fructose $\mathrm{mg}$ protein $\left.{ }^{-1} \mathrm{~h}^{-1}\right)$ by bacterial cell free extract of Treponema sp. strain $\mathrm{T}$ in the relation to growth conditions (mean values; $\mathrm{n}=6$ )

\begin{tabular}{lccc}
\hline Carbohydrate present & \multicolumn{3}{c}{ Carbohydrate degraded } \\
\cline { 2 - 4 } in growth medium & timothy grass fructan & inulin & sucrose \\
\hline Timothy grass fructan & $17.1 \pm 4.2^{\mathrm{a}}$ & $12.6 \pm 2.8^{\mathrm{a}}$ & $42.4 \pm 5.1^{\mathrm{b}}$ \\
Inulin & $19.1 \pm 7.1^{\mathrm{a}}$ & $14.9 \pm 3.6^{\mathrm{a}}$ & $55.9 \pm 9.4^{\mathrm{b}}$ \\
Glucose & $13.4 \pm 2.3^{\mathrm{a}}$ & $11.1 \pm 1.1^{\mathrm{b}}$ & $46.4 \pm 0.9^{\mathrm{c}}$ \\
\hline
\end{tabular}

values in the row marked with different letters differ significantly $(\mathrm{P}<0.05)$ 
Enzyme detection and identification. Zymographic studies performed following electrophoretic separation of protein revealed that the timothy fructan-degrading enzyme(s) were located just below the top of gel, regardless if the bacterial cell-free extract or its 2 fractions separated by centrifugation at $100000 \mathrm{~g}$ (Figure 3) were used.

A

B

C

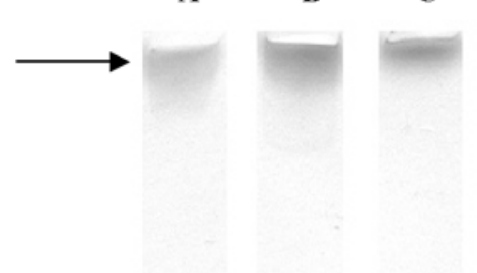

Figure 3. Zymogram of the timothy grass fructan degrading enzymes of bacteria Treponema sp. strain $\mathrm{T}$ prepared after separation of protein of bacterial cell free extract (A) and its sedimentable (B) and soluble (C) fractions by native polyacrylamide gel electrophoresis. Arrow indicates location of the identified enzyme on particular lanes

It was also found that fructose was the only end product of hydrolysis of the timothy grass fructan in the presence of all three tested preparations. Fructooligooligosaccharides as intermediate products of digestion consisting of two or more fructose residues were, however, identified when samples were analysed after $1 \mathrm{~h}$ of incubation (Figure 4).

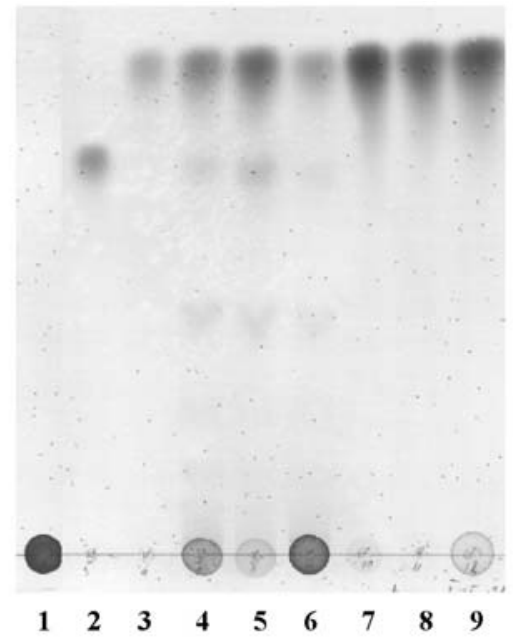

Figure 4. End products of the digestion of the timothy grass fructan by enzymes present in cell free extract of bacteria Treponema sp. strain $\mathrm{T}$ as well as its soluble and sedimentable fraction. Lanes 1, 2, 3 - the timothy grass fructan, sucrose and fructose standards, respectively; Lanes 4, 5, 6 - products released from substrate by cell free extract and its soluble and sedimentable fraction after $1 \mathrm{~h}$ of incubation, respectively; Lanes 7, 8, 9 - products released by mentioned preparations after $24 \mathrm{~h}$ of incubation 


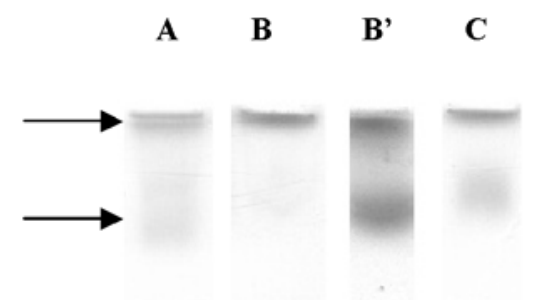

Figure 5. Sucrose degrading enzymes present in cell free extract of bacteria Treponema sp. strain T (A), and its sedimentable (B) and soluble fraction (C) identified by zymogram technique following separation of protein by electrophoresis on the sucrose containing polyacrylamide gel. B' - enzymes identified after treatment of the sedimentable fraction with Triton X-100. Arrows indicate location of the identified enzymes on particular lanes

Two protein bands exhibiting the ability to hydrolyse sucrose and characterized by different migration properties were identified in the cell-free extract and its soluble fraction (Figures $5 \mathrm{~A}$ and $\mathrm{C}$ ). The sedimentable fraction possessed a single activity located just below the top of the gel (Figure $5 \mathrm{~B}$ ).

The treatment of this preparation with Triton X-100 resulted, however, in release of another enzyme able to digest sucrose (Figure 5 B'). Its location in the gel was similar to the location of the second enzyme detected in the cell-free extract and soluble fraction (Figure 5, lane A and C). It exhibited, however, a distinctly stronger

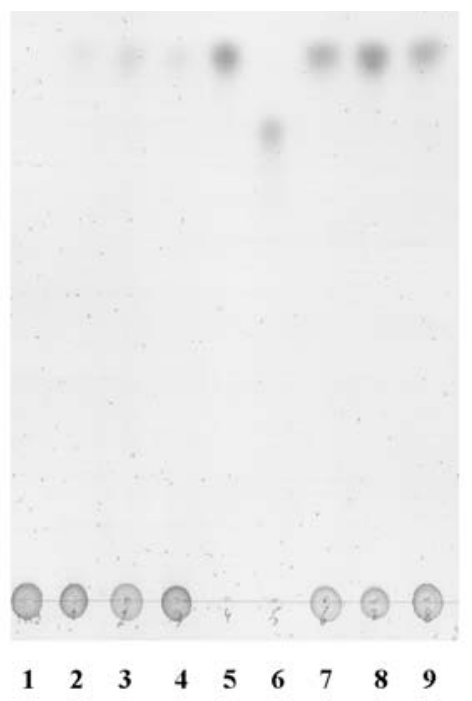

Figure 6. End products of the digestion of inulin by enzymes present in cell free extract of bacteria Treponema sp. strain $\mathrm{T}$ as well as its soluble and sedimentable fractions. Lanes 1,5 and 6 - inulin, fructose and sucrose standards, respectively; Lanes 2, 3 and 4 - products released by cell free extract and its soluble and sedimentable fractions after $1 \mathrm{~h}$ of incubation, respectively; Lanes 7, 8 and 9 products released by mentioned preparations after $24 \mathrm{~h}$ of incubation 


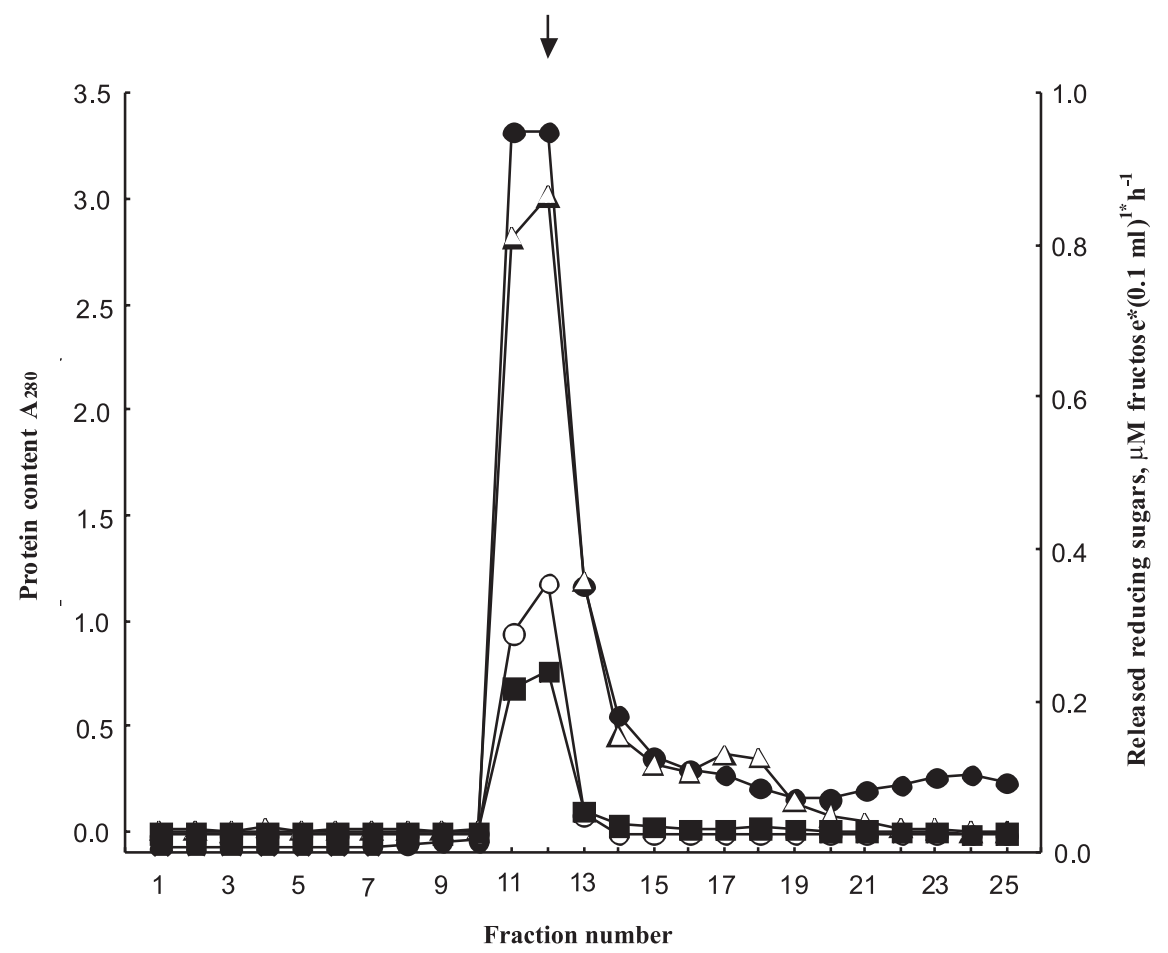

Figure 7. Elution profile of protein of the soluble fraction of cell free extract of bacteria Treponema sp., strain $T(\bullet)$ on Sephadex G-150 and its ability to degrade sucrose $(\triangle)$, the timothy grass fructan $(\circ)$ and inulin $\mathbf{m}$. Arrow indicates the void volume of column

reaction with 2,3,5-triphenyltetrazolium chloride than the other two relevant enzymes.

No inulin-degrading enzyme was detected by the zymogram technique in any of the three examined preparations. The identification of the end products of hydrolysis of inulin in the presence of the cell-free extract and its soluble and sedimentable fractions revealed that the only product of digestion was fructose. Its quantity after 1 $\mathrm{h}$ of hydrolysis was, however, just above the detection threshold (Figure 6).

Examination of the soluble fraction of the bacterial cell-free extract fractionated by gel filtration revealed that only subfraction 11,12 and 13 showed fructanolytic activity (Figure 7). All three fractions digested timothy grass fructan, inulin and sucrose and these activities were accompanied by the highest protein content. Zymographic examination of the 11 and 12 fractions pooled together showed that enzymes digesting timothy grass fructan and sucrose were located in a similar position in the gel, as it was found earlier in the case of the cell-free extract and both its fractions (see Figure 3). No inulinolytic activity was found by the zymographic technique. 


\section{DISCUSSION}

The examined bacteria were able to grow on medium supplemented with timothy grass fructan, inulin and glucose but not on sucrose or fructose. This shows that strain $\mathrm{T}$ of ruminal treponemes differs from strain $\mathrm{S}$ and the $\mathrm{kT}$ of these bacteria, which utilize either sucrose or sucrose and fructose as the sole source of carbon (Kasperowicz and Michałowski, 2002; Kasperowicz, 2005). The inability of bacteria to utilize fructose and sucrose resulted presumably from lacking a mechanism(s) to transport these carbohydrates into the cells. A similar phenomenon was observed in relation to other carbohydrates and other bacteria species from different environments (Hopkins et al., 1998).

The population density of bacteria exhibited diurnal variation composed of two periods. It increased during the first 11-13 h of incubation and then decreased or remained unchanged. The changes observed during both periods were influenced by the carbohydrate supplied to the medium. Thus, the presented findings are in accordance with the earlier data concerning Treponema saccharophilum (Paster and Canale-Parola, 1985) as well as Treponema sp., strain S and kT (Kasperowicz and Michałowski, 2002; Kasperowicz, 2005).

The cultured bacteria utilized significantly less carbohydrate from the medium supplemented with inulin compared with timothy grass fructan and glucose; one of the possible explanations for the observed difference seems to be the inability or a strongly reduced ability of the cultured treponemes to use $\beta-2,1$ fructose polymers. Such a suggestion results from the presence of undigested long-chain inulin in the post-culture medium. Thus, the quantity of carbohydrates truly available to the bacteria growing on commercial inulin was smaller compared with those grown on the other two carbohydrates, resulting presumably in a less dense population of bacteria able to survive under such growth conditions. No restrictions in utilization of timothy grass fructan and glucose were observed and this resulted in a higher growth rate of bacteria on the medium supplemented with these two carbohydrates compared with the one containing inulin. On the other hand, the lack of a source of available energy and/or high concentration of end products of bacterial metabolism in the culture medium can be responsible for the changes in bacterial number observed during the last 11-13 $\mathrm{h}$ of the incubation period.

Bacterial cell-free extract degraded timothy grass fructan, inulin, and sucrose but the last carbohydrate was degraded most rapidly. Thus, the bacteria examined in this study differ from strain S and $\mathrm{kT}$ of ruminal treponemes, which degraded sucrose many times more slowly than timothy grass fructan (Kasperowicz and Michałowski, 2002; Kasperowicz, 2005). On the other hand, the degradation rate of particular carbohydrates did not change visibly in relation to the carbon source of the incubation medium. This enabled us to hypothesize about the constitutive 
nature of the enzymes involved in the degradation of sucrose and both fructose polymers. A similar relationship was found in the case of two other strains of ruminal treponemes from our collection (Kasperowicz, 2005). In contrast to the mentioned strains of treponemes, the carbohydrates added to the culture medium visibly induced the synthesis of relevant fructanolytic enzymes by Butyrivibrio fibrisolvens, suggesting their inducible character (Cendrowska et al., 2006). Thus, the nature of synthesis of the fructanolytic enzymes seems be species specific in the case of the mentioned bacteria.

Bacterial cell-free extract and its sedimentable and soluble fractions revealed similar fructanolytic activity and degraded timothy grass fructan, inulin and sucrose to simple sugars. In contrast to this, the fractionation of cell-free extract of ruminal treponeme strains $\mathrm{S}$ and $\mathrm{kT}$ was accompanied by separation of enzymes specifically degrading timothy grass fructan from those that were able to digest all three substrates. These two types of enzymes were specific endolevanase (EC 3.2.1.65) and nonspecific $\beta$-fructofuranosidase (EC 3.2.1.26 and/or EC. 3.2.1.80). They were associated with the sedimentable and soluble faction of bacterial cellfree extract, respectively (Kasperowicz and Michalowski, 2002; Kasperowicz, 2005). Moreover, our recent studies (unpublished) confirmed the suggestion that endolevanase of strain $\mathrm{S}$ was an outer membrane-associated hydrolase. Unfortunately, we did not succeed in the separation and identification of enzymes present in the cell-free extract of treponemes examined in these studies. The presence of a specific endolevanase is, however, suggested by results of the identification of carbohydrates in the post-culture medium supplemented with timothy grass fructan, as the only carbohydrates identified there were fructooligosaccharides of different length. These findings also suggest that the specific endolevanase or its catalytic domain was associated with the outer membrane of the bacterial cell. The absence of fructanolytic enzymes in the culture medium seems to support the supposed localization of the mentioned enzyme. On the other hand, the ability of the cell-free extract and its two fractions to degrade timothy grass fructan, inulin and sucrose to simple sugars could indicate the presence of other enzyme(s), probably of unspecific $\beta$-fructofuranosidase(s). It is supposed that the enzyme is located in the intracellular space of bacteria and participates in degradation of 2,1- as well as 2,6-fructooligosaccharides to fructose. The inability of living bacteria to utilize long-chain inulin and sucrose argue for such a localization.

All of the prepared zymograms revealed that the identified enzymes were located in the same place on the gel, regardless if the substrate was timothy grass fructan or sucrose and if the cell-free extract or either of its two fractions was the source of enzymes. Additionally the detected enzyme(s) exhibited very small electrophoretic mobility. We also found that during the filtration of the soluble fraction of the cell-free extract on Sephadex G-150, the enzymes were eluted with the void 
volume of the column, as determined by blue dextran with a molecular weight of $2 \times 10^{6}$. The mentioned results suggest that the identified enzyme(s) might be associated with or belong to a large-sized molecule. This hypothesis does not preclude the presence in the examined preparations of another enzyme that is not associated with the supposed molecule. However, the appearance of such an enzyme resulting from the treatment of the sedimentable fraction with Triton X-100 seems rather to suggest its dissociation from the mentioned complex.

\section{REFERENCES}

Cendrowska M., Kasperowicz A., Michałowski T., 2006. The preliminary studies on the capability of rumen bacteria Butyrivibrio fibrisolvens to utilize fructose polymers for growth. J. Anim. Sci. 15, Suppl., 11-14

Chesson A., Forsberg C.W., 1997. Polysaccharide degradation by rumen microorganisms. In: P.N Hobson, C.S. Stewart (Editors). The Rumen Microbial Ecosystem. Blackie Academic and Professional. London, Weinheim, pp. 329-381

Gabriel O., Wang S.-F., 1969. Determination of enzymatic activity in polyacrylamide gels. Anal. Biochem. 27, 545-554

Guczyńska W., 1999. Substrate preferences some of rumen bacteria toward metabolizing sugars (in Polish). PhD. Thesis. The Kielanowski Institute of Animal Physiology and Nutrition, Polish Academy of Sciences. Jabłonna (Poland)

Holdeman L.V., Moore W.E.C., 1973. Anaerobe Laboratory Manual. 2nd Edition. The Virginia Polytechnic Institute and State University Anaerobe Laboratory. Blacksburg, VA

Hopkins M.J., Cummings J.H., Macfarlane G.T., 1998. Inter-species differences in maximum specific growth rates and cell yields of bifidobacteria cultured on oligosaccharides and other simple carbohydrate sources. J. Appl. Microbiol. 85, 381-386

Hungate R.E., 1969. A roll tube method for cultivation of strict anaerobes (IV). In: J.R. Norris, D.W. Ribbons (Editors). Methods in Microbiology. Vol. 3B. Academic Press, London and New York, pp. 117-132

Kasperowicz A., 2005. The characterization of fructanolytic activity of the rumen bacteria from the genus Treponema (in Polish). PhD. Thesis. The Kielanowski Institute of Animal Physiology and Nutrition, Polish Academy of Sciences. Jabłonna (Poland)

Kasperowicz A., Michałowski T., 2002. Assessment of fructanolytic activities in the rumen bacterium Treponema saccharophilum strain S. J. Appl. Microbiol. 92, 140-146

Koizumi K., Utamura T., Okada Y., 1985. Analyses of homogeneous D-gluco-oligosaccharides and -polysaccharides (degree of polymerization up to about 35) by high performances liquid chromatography and thin layer chromatography. J. Chromatogr. 321, 145-157

Lüscher M., Frehner M., Nösberger J.I., 1993. Purification and some properties of fructan: fructan fructosyl transferase from dandelion (Taraxacum officinale Weber). New Phytol. 123, 437-442

Mäntsala P., Zalkin H., 1979. Membrane-bound and soluble extracellular $\alpha$-amylase from Bacillus subtilis. J. Biol. Chem. 254, 8540-8547

Miller G.L., Blum R., Glennon W.E., Burton A.L., 1960. Measurement of carboxymethylcellulase activity. Anal. Chem. 2, 127-132 
Paster B.J., Canale-Parola. E., 1985. Treponema saccharophilum sp. Nov., a large pectinolytic spirochete from the bovine rumen. Appl. Environ. Microbiol. 50, 212-219

Smith P.K., Krohn R.J., Hermanson G.T., Mallia A.K., Gartner F.H., Provenzano M.D., Fujimoto E.K., Goeke N.M., Olson B.J., Klenk D.C., 1985. Measurement of protein using bicinchoninic acid. Anal. Biochem. 150, 76-85

Southgate D.A., 1991. Determination of Food Carbohydrates. 2nd Edition. Elsevier Applied Science, London and New York

Thomas G.J., 1960. Metabolism of the soluble carbohydrates of grasses in the rumen of the sheep. J. Agr. Sci. 4, 360-371

Wise C.S., Dimler R.J., Davis H.A., Rist C.E., 1955. Determination of easily hydrolysable fructose units in dextran preparations. Anal. Chem. 27, 33-36

Ziołecki A., Guczyńska W., Wojciechowicz M., 1992. Some rumen bacteria degrading fructan. Lett. Appl. Microbiol. 15, 244-247 